\title{
THE LARGE BUSINESSES OF RUSSIA: AN INDUSTRY ANALYSIS Viktor Barkhatov ${ }^{1}$, Daria Bents ${ }^{2}$, Irina Belova ${ }^{3}$, Yuner Kapkaev $^{4}$
}

\begin{abstract}
The aim of the article is to analyze the distribution of large Russian enterprises in key areas of activity within each federal district. Analytical and review articles concern problems of large, medium and small businesses, their role in the national economy and regional economic policy, problems of interaction between the state and business structures are the basis of theoretical and methodological approach of this research. The information base for this research is the data of accounting and tax reporting of large Russian enterprises in 2016. This data was provided by the First Independent Rating Agency. We show an uneven distribution of large enterprises across the Russian territory. More than a half of the large-sized enterprises are located in the Central Federal District. We identify areas of activity peculiar to large enterprises in each federal district and also areas of activity that are not very popular among large businesses. In the majority of regions, the greatest percent of the enterprises are presented by wholesale and retail trade. On the second place there are the enterprises of the manufacturing industry. As for mining, large business is concentrated in those regions where minerals are extracted. Among the least popular sectors are the spheres of research and development. The results will be a platform for further evaluation of the contribution of large business to the welfare of Russian regions.
\end{abstract}

JEL Classification Numbers: D600, O120; DOI: http://dx.doi.org/10.12955/cbup.v6.1127

Keywords: large business, large Russian enterprises, federal district, regions, key fields of activity, welfare of regions

\section{Introduction}

The importance of the enterprise sector, irrespective of its size and field of activity, is irrefutable for the economy of any country. There are set of empirical researches and economic theories that confirm this idea. Both the classical macroeconomic theory, and the Keynesian theory, that stands up for state intervention in the economy. All these economic theories can make the common conclusion for the necessity of growth and development of the enterprise sector. This is because the enterprise sector starts the "flywheel" of production, crediting and consumption, which as a result allows to increase the welfare of all economic agents. However, today's realities have shown insolvency of both many microeconomic, and macroeconomic theories. Today, often subjects of political, economic and business elite unanimously express the disposal needs of Russian "narrow-mindedness" (the term of the Russian President). Russia has to get rid of its dependence on the world energy market. It is necessary to create and develop a full cycle of Russian production in all key industries, beginning from the resource base and finishing with a ready-made product. Today the key principle of the liberal economy (the principle of "lasses-faire" which describes non-interference of the state in the economy) has also shown insolvency. It is important to highlight that this is not about a permanent regulation of business. Contrary to this, it is suggested to give more freedom and power to business, therefore allowing them to grow and prosper. The point of the matter is that the state should create institutional conditions for the growth and development of business. Today the trend of globalization and liberalization of the international market has been replaced by national security priorities. Therefore, the Russian economy has to grow and develop comprehensively, and not just through production and the sale of raw material resources. Only a strong, far and wide developed economy can ensure economic security, including constant and stable food provision for itself. Business as it by the nature is "the investment engine" of the Russian economy has to not play the last role.

The purpose of this study is to analyze the key areas of activity of the largest Russian enterprises. This research, along with research conducted earlier by V. Barkhatov and colleagues (Barkhatov et al. 2017), will be a platform for further evaluation of the contribution of large businesses to the welfare of Russian regions.

\section{Materials and Methods}

Analytical and review articles concern problems of large, medium and small businesses, their role in the national economy and regional economic policy, problems of interaction between the state and business structures are the basis of the theoretical and methodological approach of this research. The information base for this research is the data of accounting and tax reporting of large Russian

\footnotetext{
${ }^{1}$ Chelyabinsk State University, ieo-science@csu.ru

${ }^{2}$ Chelyabinsk State University, benz@csu.ru

${ }^{3}$ Chelyabinsk State University, belova@csu.ru

${ }^{4}$ Chelyabinsk State University, zam@csu.ru
} 
enterprises in 2016. We allocated fields of activity of the large enterprises according to the Russian Classifier of Economic Activities (RCEA). This data as provided by the First Independent Rating Agency.

The general scientific methods of economic science, including methods of comparative and graphic analysis, induction, deduction and synthesis are used as methodological instruments of this research. As in literature and the standard legislative base there is no accurate definition of the concept of "large business", we'll consider enterprises as "large businesses" if they have sales more than 2 billion rubles (about 28.8 million euros). The selection includes 8894 large enterprises. We have analyzed, first, the territorial distribution of these enterprises among the federal districts, and secondly, the distribution between the fields of activity according to the Russian Classifier of Economic Activities (RCEA). This Classifier (RCEA) includes 21 sections. The sections, in turn, include 88 classes.

The distribution of the large enterprises among federal districts and between fields of activity according to RCEA is presented in Figure 1.

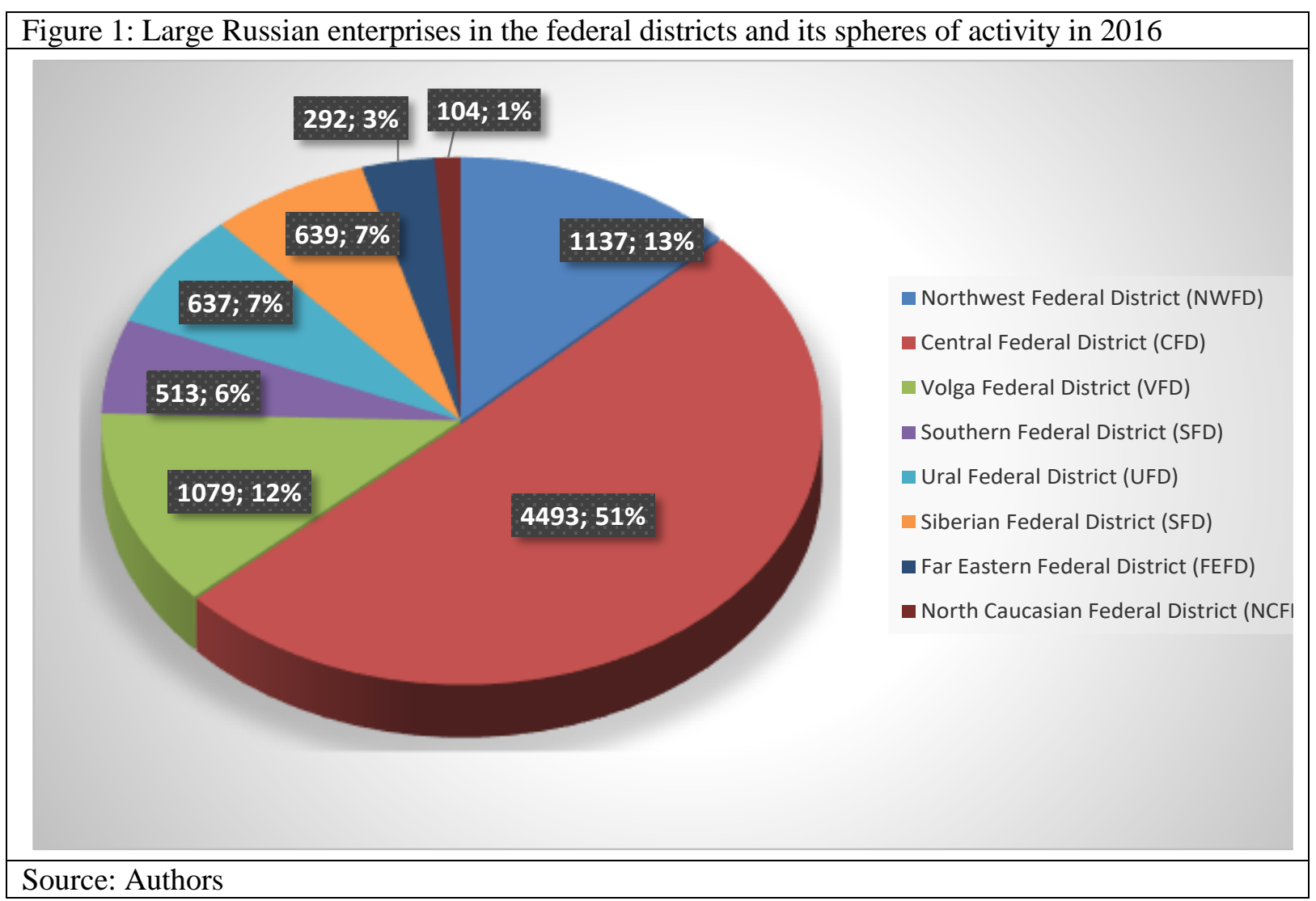

\section{Results}

A closer inspection of Table 1 allows us to make a number of interesting conclusions. First of all, we can see an uneven spatial distribution of large enterprises across Russia. Around $51 \%$ of large enterprises are located in the Central Federal District, where Moscow is the administrative center. The distribution of the remaining $49 \%$ of large enterprises across the other districts may also be described as uneven and heterogeneous. Secondly, there is no single federal district representing all spheres of activity by large enterprises according to the sections and classes of RCEA. Thirdly, the number of spheres of activity of large enterprises is greater in those districts where the number of enterprises is greater by itself. A good example is the Central Federal District, the Northwest Federal District and the Volga Federal District.

We then closer analyzed the distribution of large enterprises by spheres of activity within each federal district of Russia. For achievement of the greatest presentation, we have grouped the data according to sections of the RCEA. At the same time, we don't show classes and subclasses. Moreover, in the tables below we don't show the enterprises that have a weight in the general structure of the sections of the RCEA on each district less than $1 \%$. 
The distribution of the large enterprises between the fields of activity in Central, Northwest, Volga and Siberian Federal Districts in 2016 is presented in Table 2.

Table 2: Distribution of large business enterprises in Central, Northwest, Volga and Siberian Federal Districts by areas of activity in $2016, \%$

\begin{tabular}{|l|c|c|c|c|}
\hline \multicolumn{1}{|c|}{ Areas of activity } & $\begin{array}{c}\text { Central } \\
\text { Federal } \\
\text { District } \\
\text { (CFD) }\end{array}$ & $\begin{array}{c}\text { Northwest } \\
\text { Federal } \\
\text { District } \\
\text { (NWFD) }\end{array}$ & $\begin{array}{c}\text { Volga Federal } \\
\text { District (VFD) }\end{array}$ & $\begin{array}{c}\text { Siberian Federal } \\
\text { District (SFD) }\end{array}$ \\
\hline Wholesale and retail trade & 47 & 40 & 31 & 35 \\
\hline Manufacturing Industry & 16 & 24 & 32 & 16 \\
\hline Mining & - & 2 & 8 & 5 \\
\hline Building & 8 & 11 & 7 & 9 \\
\hline Electricity, gas, steam supply & 3 & 4 & 7 & 6 \\
\hline $\begin{array}{l}\text { Rural, forestry, hunting, } \\
\text { fishery and fish farming }\end{array}$ & 2 & 3 & 3 & - \\
\hline Transportation and storage & 4 & 6 & 3 & 3 \\
\hline $\begin{array}{l}\text { Financial and insurance } \\
\text { activity }\end{array}$ & 7 & 2 & 4 & - \\
\hline $\begin{array}{l}\text { Professional, scientific, } \\
\text { technical activity }\end{array}$ & 7 & 5 & - & - \\
\hline $\begin{array}{l}\text { Information and } \\
\text { communication activity }\end{array}$ & 3 & 1 & - & - \\
\hline Real estate transaction & 3 & 1 & 2 & - \\
\hline $\begin{array}{l}\text { Water supply and water } \\
\text { disposal }\end{array}$ & - & - & & - \\
\hline Source: Calculated by authors with data of the First Independent Rating Agency (www.fira.ru) \\
\hline
\end{tabular}

A common feature representing the distribution of large enterprises in the spheres of activity in the Central Federal District is the concentration of about $47 \%$ of large enterprises in wholesale and retail sectors. At the same time, the vast majority of these enterprises are engaged in wholesale trade, except for trade in vehicles and motorcycles. The sphere of the manufacturing sector is presented by the enterprises occupied in the production of foodstuff, production of chemicals and chemical products, and the production of rubber and plastic products. A small part of large enterprises are engaged in light industry, including the production of clothing, footwear and textiles. Less than $1 \%$ of the sectoral structure of large enterprises represent mining, water supply and sanitation, hotel and public catering establishments, education, healthcare, cultural, sports and leisure activities.

The same situation is observed in the Northwest Federal District. The largest number of enterprises is concentrated in wholesale and retail trade. Comparing the Northwest Federal District to the Central Federal District, the other spheres of activity of large enterprises largely coincide (except for mining of minerals, water supply and sanitation in the NWFD) and have approximately the same share in the industry structure. Manufacturing industries of the NWFD district are almost identical to the CFD. The activity of hotels and public catering enterprises, activities in the field of public health, culture, sports, leisure, administrative and related services also occupy less than $1 \%$ in the sectoral structure of large businesses in the Northwest Federal District.

There is a number of general patterns of distribution of large enterprises in the areas of activity at the Volga and Siberian federal districts. In particular, the dominant share is occupied by large enterprises engaged in wholesale and retail trade, the two are roughly the same in size $(31 \%$ and $35 \%$ respectively). A similar situation is observed in the sphere of construction, agriculture and forestry. However, these is a distinctive difference in the distribution of large enterprises in the spheres of activity in the Volga Federal District in terms of their dominance (with a slight advantage) of the sphere of manufacturing industries over the wholesale and retail trade. In the structure of manufacturing industries VFD and SFD leadership occupy similar areas, as in the Central Federal District. Less than $1 \%$ in the sectoral structure of large business VFD is engaged in activities of information and communication, real estate transactions, leasing, entertainment such as culture, sports and leisure. In the sectoral structure of large enterprises of the Siberian Federal District, less than 1\% 
are occupied by public catering activities, financial and insurance activities, as well as areas specific to the Volga Federal District.

The distribution of large business enterprises according to the areas of activity in Southern , Ural , North Caucasian and Far Eastern Federal Districts in 2016 is presented in the Table 3.

Table 3: Distribution of large business enterprises in Southern, Ural, North Caucasian and Far Eastern Federal Districts by areas of activity in 2016,\%

\begin{tabular}{|l|c|c|c|c|}
\hline \multicolumn{1}{|c|}{ Areas of activity } & $\begin{array}{c}\text { Southern } \\
\text { Federal } \\
\text { District } \\
\text { (SFD) }\end{array}$ & $\begin{array}{c}\text { Ural } \\
\text { Federal } \\
\text { District } \\
\text { (UFD) }\end{array}$ & $\begin{array}{c}\text { North Caucasian } \\
\text { Federal District } \\
\text { (NCFD) }\end{array}$ & $\begin{array}{c}\text { Far Eastern } \\
\text { Federal District } \\
\text { (FEFD) }\end{array}$ \\
\hline Wholesale and retail trade & 43 & 27 & 38 & 29 \\
\hline Manufacturing Industry & 25 & 24 & 22 & 7 \\
\hline Mining & 2 & 16 & 2 & 17 \\
\hline Building & 7 & 9 & 6 & 7 \\
\hline Electricity, gas, steam supply & 7 & 7 & 16 & 13 \\
\hline $\begin{array}{l}\text { Rural, forestry, hunting, } \\
\text { fishery and fish farming }\end{array}$ & 4 & 3 & 7 & 3 \\
\hline Transportation and storage & 10 & 4 & 6 & 3 \\
\hline $\begin{array}{l}\text { Financial and insurance } \\
\text { activity }\end{array}$ & - & 2 & 2 & - \\
\hline $\begin{array}{l}\text { Professional, scientific, } \\
\text { technical activity }\end{array}$ & - & - & - & - \\
\hline $\begin{array}{l}\text { Information and } \\
\text { communication activity }\end{array}$ & - & - & - & - \\
\hline Real estate transaction & - & - & - & 3 \\
\hline $\begin{array}{l}\text { Water supply and water } \\
\text { disposal }\end{array}$ & - & 3 & 1 & - \\
\hline
\end{tabular}

Several conclusions we can make from the analysis. Firstly, the wholesale and retail trade also hold a leading position in the sectoral structure of large businesses. However, the share of such enterprises in the SFD is sufficiently higher in comparison to the UFD, $47 \%$ against $27 \%$. Secondly, the share of large enterprises engaged in the extraction of minerals is significantly higher in the Ural region (16\% against $2 \%$ ), which is mainly achieved through the extraction of crude oil and other minerals located in the territory of that district. Thirdly, the share of large enterprises engaged in manufacturing in both districts is almost identical. As for the structural composition of manufacturing industries, in contrast to the SFD, a dominant role is allotted to metallurgy in the UFD. Interestingly enough, less than $1 \%$ in the structure of large businesses by sector in the SFD and UFD share similar areas of activity when compared to the Volga Federal District and the Siberian Federal District.

As for the North Caucasian and Far East federal districts, we can see that wholesale and retail trade dominates in the distribution of business activity of large businesses, as in all the districts presented earlier. In addition, several distinctive sectoral structure features may be highlighted. The Far Eastern Federal District is largely dominated by agriculture, forestry, hunting, fishing and fish farming (through fishing and fish farming). The NCFD, on the other hand, the dominant share is allotted to the provision of electricity, gas and steam. Interestingly, there are no spheres of business activity in the NCFD region with a weight of less than $1 \%$ of the total sectoral structure. In the Far Eastern Federal District less than $1 \%$ of the sectoral structure of large businesses occupy similar areas of activity when compared to the Volga Federal District, the Siberian Federal District, the Southern Federal District and the Ural Federal District.

\section{Literary Review}

The influence of large business on the innovative potential and infrastructure of the regions and its role in the national economy has been studied by Safina (2013), and Vanieva and Abdulbakieva (2017). A comparative analysis of the functioning of large businesses in the regions of the Russian Federation and their impact on the economy have been revealed by Zubarevich (2005). Tendencies in the development of large corporations in Russia, the mechanisms of interaction between the state bodies 
and large business structures at the territory of their operations were investigated by Sokurenko (2014), and Belyaeva and Danilova (2014, 2015). The study of the role of large businesses in the formation of regional economic policy has been substantially covered by Kashina (2013) and Razgulina (2014).

Substantial research has been conducted by Akhtariev (2011), Meshcheryakova (2011), and Savchenko (2008), who analyzed the various forms of interaction between small and large businesses, including their integration, mergers and acquisitions, ways of cooperation, forms of partnership as well as state support for their interaction. However, in reality such practice of interaction is extremely rare in nature. The reasons explaining the lack of interaction between large and small businesses are numerous, such as imperfection in the legislation, which is the most important one; tax legislation; insufficient number of effective state support programs aimed at provision of such interaction, etc. Small and medium businesses along with large businesses serve as the foundations of the Russian economy. However, their potential has not been fully studied, which is stated in the paper by Barkhatov and colleagues $(2016,2017)$.

The study of the role of large business, the problems of its functioning in the economies of other countries, has also been conducted by foreign colleagues. The influence of the regional institutional environment on the capital structure of small and medium-sized enterprises in Spain was discovered by Pietro et al. (2017). Factors influenced the successful functioning of the business was carried out by Perez and Rodriguez Del Bosque (2015). In particular, the influence of businesses on the economic growth of the regions of Latvia has been investigated by Krumins et al. (2015). Kirdasinova et al. (2016) assessed the current state of large and small businesses in Kazakhstan. Langvinienè \& Daunoravičiūte (2015) conducted research with the core aim to analyze factors that influence the successful operation of businesses in certain areas of activity in Lithuania. Comparative analysis on the possibilities and needs of businesses of different size in India and China was conducted by researchers from the Indian Institute of Management (Sahasranamam \& Sud, 2016). Evaluation of the economic effect of entrepreneurship and the activity of businesses, as well as the identification of realistic expectations from the functioning of businesses, were disclosed by Summers (2015). There is also a variety of literature devoted to exploring the problems of state support of large businesses, depicting two sides of the argument in this field. On one hand, the economic community is of the opinion that the state should not interfere in the activities of large businesses. On the other hand, opposing view supports the idea of state regulation of businesses. A substantial research in this direction was conducted by Haydar (2012). He assessed the impact of business regulation reforms on economic growth in 172 countries. As a result of this research, it has been revealed that on average, any reform aimed at business regulation ultimately contributes to GDP growth of $0.15 \%$. In addition, Djankov et al. (2006) and Haidar (2009) showed that state support for business should not be burdensome, which adversely affects the growth of the economy.

\section{Discussion}

Large businesses and their importance for both national and regional economies is a relevant problem, for Russia, but not for other countries. The GDP of many countries is formed by small and mediumsized enterprises. Such enterprises, as a rule, are more flexible, adapt quickly to innovations and fast environmental changes. In Russia scientists also pay attention to small and medium business. There is a large number of state support programs for small business in Russia. But it is necessary to state that Russia is a very specific country. It has a huge territory with a large number of inhabitants. It has a densely populated center and the sparsely populated periphery. The unity of the country and the geographical integrity of territories are such tasks set to the President V. Putin today. Nevertheless, we have active discussions concerning what businesses are necessary to Russia. Many scientists claim today that large businesses correspond to requirements of the Russian economy. Contrary to neoclassical approaches of free competition and the equality of firms in the market, the question of the real importance of large business becomes more relevant for the country today. Large businesses can concentrate a huge number of resources - production, financial, information, intellectual.

Russia is a country with a specific history. There are also certain mental specifics such as the aspiration to solve problems centrally. Large businesses make up about $80 \%$ of the GNP of the country. At the same time, the share of the state participation steadily for the last $15-20$ years has remained at the level of $50 \%$. 
Whenever there were disputes around Russian businesses, it is possible to conclude the following: large Russian business have large modernization potential, they create a prevailing quantity of jobs, they pay the greatest share of taxes in all budgets (the countries and regional). Only such large businesses are capable to master the natural resources to build objects of strategic appointment (bridges, spaceports, etc.).

\section{Conclusion}

The results of the following research allow us to make a number of conclusions. First of all, the distribution of large enterprises in Russia in the geographical sense is heterogeneous and mostly uneven. The vast majority of large enterprises are concentrated in the Central Federal District (about $51 \%$ ), but this does not affect the presence of the same areas of activity in other districts. Secondly, the same areas of activity of large enterprises in each district were highlighted. This mostly represents wholesale and retail trade; manufacturing industries; construction; transportation and storage; power, gas and steam supply; agriculture, forestry, hunting, fishing and fish farming. Thirdly, Russian large businesses may be characterized by "one-sidedness" in the structure of their activity. There is a tendency for each district to have a significant bias towards wholesale and retail trade (range of variation from 27-47\%). The share of large enterprises engaged in the manufacturing industries are generally lower (range of variation from 7-32\%). The only exception is the Volga Federal District, where the share of such enterprises exceeds the share of wholesale and retail trade enterprises. The share of enterprises engaged in construction is approximately the same across the board (range of variation from $5-10 \%$ ) and does not depend on the number of large enterprises in the district. As a matter of fact, large businesses are concentrated in the mining of minerals in those regions and districts where raw materials are present, and the discovery of new deposits is still ongoing. There are areas of activity that are not very popular among big enterprises. These include activities in the field of health and social services; libraries, archives, museums and other cultural objects; state administration and military security, social security; education; veterinaries; scientific research and development.

There are numerous reasons contributing to the distribution of large businesses by the sphere of their activity. First of all, there is a tendency for large corporations to acquire technologies and necessary equipment abroad, without investing in the country's resources to develop domestic production. There is a common trait of large business enterprises in Russia to borrow existing foreign innovation projects, but not to create qualitatively new innovations. This is evidenced by a negligible share of large enterprises engaged in research and development. To ensure sustainable development of Russian regions, it is necessary to carry out further industry restructuring of large businesses. In particular, it is important to continue sustaining the growth of manufacturing industries, including machine-building production, the aircraft industry, light manufacturing industry, metallurgical production; development of the agro-industrial complex, including agricultural processing industry, plant growing, livestock, fisheries; the development of information technology and computer software.

The results of this research form the foundation for the determination of contributions of large businesses to economic growth and development of the regions in Russia. This understanding allows researchers to evaluate the effectiveness of the state's economic policies and regulations, including the impact of these policies on large businesses. The study allows us to determine whether large businesses are effective, whether they use their power to abuse the market, as well as to determine how great the tax returns from activities of such enterprises are.

\section{References}

Ahtariev, R.R. (2011). Bashkortostan Republic: the cooperation communications between large and small business. Development of economic communications between large and small business in domestic economy. Russian business, 1-2, 23-29 (In Russ.).

Barkhatov, V., \& Belova, I. (2017). External Success Factors of Small and Medium-Sized Enterprises of Russia: Economic Aspect. Country Experiences in Economic Development, Management and Entrepreneurship. Proceedings of the 17th Eurasia Business and Economics Society Conference, 5, 453-468.

Barkhatov V., Belova I., \&Bents D. (2017). Enterprises of large Russian business: the analysis of federal districts. Bulletin of the Chelyabinsk state university, 5(401), 104-113 (In Russ.).

Barkhatov V., Nikolaeva E. \& Belova I. (2016). Taxation and Transaction Costs as Factors of Business Success in MediumSized Enterprises in Russia. Entrepreneurship, Business and Economics. Proceedings of the 15th Eurasia Business and Economics Society Conference, 1, 129-137. 
Barkhatov V., Pletnev D. \& Campa A. (2016). Key Success Factors and Barriers for Small Businesses: Comparative Analysis. Procedia - Social and Behavioral Sciences, 221, 29-38.

Beljaeva I.Ju. \& Danilova O.V. (2015). Interaction of business and power: recommendations about increase in stability of territories of presence of large business. Modern corporate strategy and technologies in Russia. Collection of scientific articles, 23-34 (In Russ.).

Beljaeva I.Ju. \& Danilova O.V. (2014). Mechanisms of interaction of public authorities and large business structures in the territory of presence. Administrative sciences in modern Russia, 1, 30-34 (In Russ.).

Di Pietro F., Palacín Sánchez M.J. \& Roldán J.L. (2017). Regional development and capital structure of SMEs. Cuadernos de Gestión. Available at http://www.ehu.eus/cuadernosdegestion/revista/en/online-first/onlinefirst/368 [Accessed 20 December 2017].

Djankov S., McLiesh C. \& Ramalho R. (2006). Regulation and growth. Econ. Letters, 92(3), 395-401.

Haidar, J. I. (2012). The Impact of Business Regulatory Reforms on Economic Growth. Journal of The Japanese and International Economies, 26, 285-307.

Haidar, J.I. (2009). Investor Protections and Economic Growth. Econ. Letters, 103(1), 1-4.

Kashina, E.A. (2013). Role of large business in formation of regional policy of the Russian state: raw aspect. National security, 5, 35-50 (In Russ.).

Kirdasinova K. A., Muftigalieva A. A., Zhanseitova G. S., Demessinov T. Zh., Kurmanov N. A., Baitenova L. M., \& Selezneva I.V. (2016). Current State of Business Development in Kazakhstan. Journal of Advanced Research in Law and Economics, Vol.VII, Issue 2(16), 260-269.

Krumins G., Krumina I. \& Rozentale S. (2015). Preconditions for Regional Economic Growth at the District Level in Vidzeme, Latvia. Procedia - Social and Behavioral Sciences, 213, 117-122.

Langvinienè N. \& Daunoravičiūtė I. (2015). Factors Influencing the Success of Business Model in the Hospitality Service Industry. Procedia - Social and Behavioral Sciences, 213, 902-910.

Meshherjakova, S.A. (2011). The state support of interaction of small business with large business. Bulletin of the Kazan state financial and economic institute, 3, 35-39 (In Russ.).

Pérez A. \& I. Rodríguez del Bosque (2015). Identidad, imagen y reputación de la empresa: integración de propuestas teóricas para una gestión exitosa. Cuadernos de Gestión, 14(1), 97-126. Available at

http://www.ehu.eus/cuadernosdegestion/revista/en/published-issues/articulo?year=2014\&vol=14\&num=1\&o=5. [Accessed 20 December 2017].

Razgulina, E.D. (2014). Large business as reference point of regional economic policy. Economy and management of innovative technologies, 2(29), P.15 (In Russ.).

Safina, G.R. (2013). Influence of large business on innovative potential and business infrastructure of regions. Discussion, 8(38), 80-82 (In Russ.).

Sahasranamam S. \& Sud M. (2016). Opportunity and Necessity Entrepreneurship: a Comparative Study of India and China. Academy of Entrepreneurship Journal, Vol.22, No.1, 21-40.

Savchenko, L.A. (2008). Forms and effects of the economic interaction between small and large business. Terra Economicus, Vol.6, Issue 1-3, 291-295 (In Russ.).

Sokurenko, A.P. (2014). Tendencies of development of large business in Russia. Scientific and methodical Concept online journal, Vol.20, 3706-3710 (In Russ.).

Summers, D. (2015). The Economic Impact Of Entrepreneurship: Setting Realistic Expectations. Academy of Entrepreneurship Journal, Vol. 21, No.2, .99-107.

Vanieva M. \& Abdul'bakieva S.I. (2017). Role of large business in economy of Russia. Registration and analytical ensuring strategy of sustainable development of the enterprise. Proceedings of the international scientific and practical conference, 70 73 (In Russ.).

Zubarevich, N.V. (2005). Large business in regions of Russia: territorial development strategies and social interests. Analytical report. Moscow: Pomatur, 101p. (In Russ.). 